\title{
Indirect pulp treatment without re-entry in a permanent tooth: 36 months of follow-up
}

\author{
Tratamento pulpar indireto sem reabertura em dente permanente: acompanhamento de 36 meses
}

\author{
Giovanna Izola SIMONE'1 \\ Carolina STEINER-OLIVEIRA² \\ Mariana Minatel BRAGA' \\ José Carlos Pettorossi IMPARATO'
}

\begin{abstract}
An alternative approach in the management of deep caries lesions is the indirect pulp treatment, without re-entry in the cavity. It has been shown that the complete removal of the carious dentin became unnecessary after the total tooth sealing, because the remaining microorganisms of the affected dentin would stop proliferating and/or die. This case report describes the management of a deep caries lesion of an 11-year-old girl with great coronary destruction in the left mandibular permanent first molar. Infected dentinal walls were excavated with manual instruments and the remainder affected dentin was filled with ionomer glass cement and composite resin. After 36 months of followup, no clinical and radiographic signs and symptoms of pulp damage were observed. In conclusion, the indirect pulp treatment was considered a good alternative for the treatment of deep caries lesions as it reduced the risk of pulp exposure by not reopening the cavity, saved the patient and the dentist clinical time and arrested the lesion progression with radiographic density increase and absence of any pain symptoms.
\end{abstract}

Indexing terms: Dental caries. Dental pulp capping. Longitudinal studies. Permanent dentition.

\section{RESUMO}

Um novo conceito clínico no tratamento de lesões de cárie profunda é o tratamento pulpar indireto sem reabertura da cavidade. Tem sido demonstrado que a remoção completa da dentina cariada tornou-se desnecessária após selamento total do dente, pois os microorganismos remanescentes da dentina afetada não se proliferariam ou morreriam. Este relato de caso descreve o tratamento de lesões de cárie profunda de uma menina de 11 anos de idade com grande destruição coronária no primeiro molar permanente mandibular. As paredes dentinárias infectadas foram removidas com instrumentos manuais e a dentina afetada remanescente foi preenchida com cimento de ionômero de vidro e resina composta. Após 36 meses de acompanhamento, não se observou nenhum sinal e sintoma clínico e radiográfico de dano pulpar. Em conclusão, o tratamento pulpar indireto foi considerado uma boa alternativa para o tratamento de lesões de carie profunda, já que reduziu o risco de exposição pulpar, devido a não reabertura da cavidade, economizou tempo clínico para o paciente e o dentista e paralisou a progressão da lesão com aumento da densidade radiográfica e ausência de qualquer sintomatologia dolorosa.

Termos de indexação: Cárie dentária. Capeamento da polpa dentária. Estudos longitudinais. Dentição permanente.

\section{INTRODUCTION}

Dental caries is recognized as an infectiouscontagious disease that results in a located minerals loss from affected teeth, caused by organic acids proceeding from dietary carbohydrate microbial fermentation. This chronic disease has a multifactorial aspect and depends on the interaction between the teeth, saliva, microbiota and dietary habits ${ }^{1}$. In deep caries lesion treatment, two methods have been suggested: Indirect pulp-capping procedure and Stepwise excavation (two-stage excavation procedure). In the indirect pulp-capping procedure, the carious dentin is almost completely removed, leaving a thin layer of residual demineralized dentin and the reentry is not undertaken ${ }^{2-5}$. This procedure is somewhat invasive and the accidental pulp exposure is expected. On the other hand, in the stepwise excavation the carious dentin is partially removed, the tooth is sealed with glassionomer cement and resin for about 45 - 60 days, when reparative or sclerotic dentin is expected to be formed. After that period, the cavity is reopened and the remaining carious dentin is completely removed so the cavity can be permanently restored ${ }^{4,6}$.

\footnotetext{
${ }^{1}$ Universidade de São Paulo, Faculdade de Odontologia, Departamento de Odontopediatria. Av. Prof. Lineu Prestes, 2227, Cidade Universitária, 05508-900, São Paulo, SP, Brasil. Correspondência para / Correspondence to: GI SIMONE. E-mail: <gisimone@terra.com.br>.

${ }^{2}$ Universidade Estadual de Campinas, Faculdade de Odontologia, Departamento de Odontopediatria. Piracicaba, SP, Brasil.
} 
However, some authors have already shown that the reopening, to complete remove the carious dentin, became unnecessary after the total tooth sealing, because there is a drastic reduction of bacteria after incomplete removal of soft dentin and cavity sealing for prolonged time $^{6-8}$. The residual bacteria would be isolated from nutrient sources, would stop proliferating and consequently die.

A new clinical concept in the management of deep caries lesions is the indirect pulp treatment, without reentry in the cavity 5,9 . The infected dentin is totally removed from the lateral walls with an excavator, remaining only a soft thin layer in the pulp wall ${ }^{10}$. Glass-ionomer cement or calcium-hydroxide can be used, but only in the pulp wall and after that, the cavity is totally sealed with resin. This technique does not require re-entry to caries complete removal.

The indirect pulp treatment is limited to teeth that do not present signs of irreversible pathologies or mobility based on a complete clinical and radiographic examination. Thus, the aim of this study was to describe the management of a deep caries lesion of a permanent first molar using a new clinical concept known as indirect pulp treatment without re-entry in the cavity.

\section{CASE REPORT}

An 11-year-old girl was brought to the Adolescent Dental Clinic at São Paulo University, SP, Brazil in 2004 for regular treatment. The anamnesis was carefully undertaken to obtain information about oral health care and clinical and radiographic exams were also performed. Her past medical history was found to be non-contributory and within normal limits.

At the clinical examination, an extent deep caries lesion was observed at the left mandibular permanent first molar (Figure 1). The initial periapical radiography revealed deep carious lesion with proximity to the pulp chamber of the left mandibular permanent first molar (Figure 2). The indirect pulp treatment was conducted. Under local anesthesia, the cavity was accessed firstly with diamond bur to remove the non-supported enamel and after that, the dentinal walls were excavated with manual instruments (Figure 3). The infected dentin was removed of the floor of the carious cavity. The remainder affected dentin was filled with ionomer glass cement (Vitromolar, DFL, Rio de Janeiro, Brazil). After 6 months, this restoration was partially removed, without re-entry, so composite resin $\left(Z 100^{\circledR}, 3 \mathrm{M} / \mathrm{ESPE}\right.$, St. Paul, MN, USA) could be placed as a definitive restoration (Figure 4). The steps were teeth isolation with rubber dam; 37\% phosphoric acid (3M/ ESPE, St. Paul, MN, USA) etching; water rinse, gentle air dry; application of two layers of Single Bond adhesive ${ }^{\circledR}$ (3M/ESPE St. Paul, MN, USA) and light-curing following the manufacturer's instructions; application of light cured composite resin $\mathrm{Z100}^{\circledR}$ (3M/ESPE, St. Paul, MN, USA); light curing; finishing and polishing.

The patient has been attending the Adolescent Dental Clinic for follow-up, but we could not get in contact with her in the year of 2006. Nowadays, after 3 years of follow-up, there are signs and symptoms of pulp vitality such as absence of spontaneous pain, absence of heat/ cold sensitiveness, absence of abnormal dental mobility or abscess formation and absence of radiographic image suggestive of periapical lesion (Figure 5).

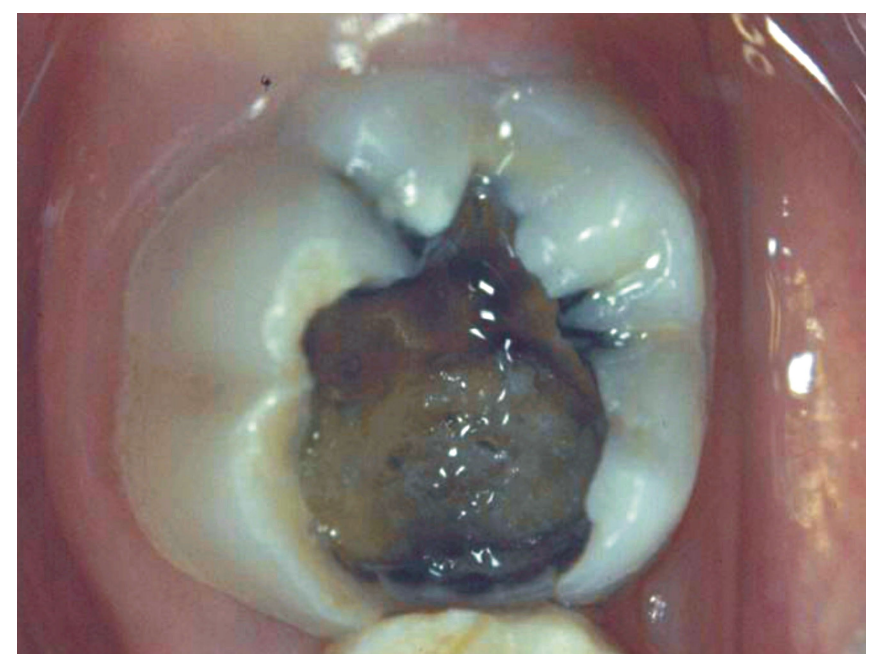

Figure 1. Deep caries lesion in the left mandibular permanent first molar with large accumulations of cariogenic biomasses.

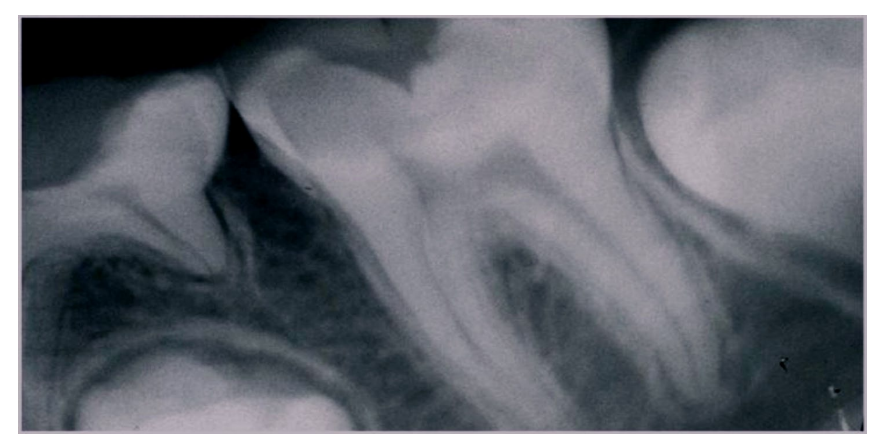

Figure 2. The pretreatment radiograph showing deep carious lesion into the dentin very close to the pulp complex. 


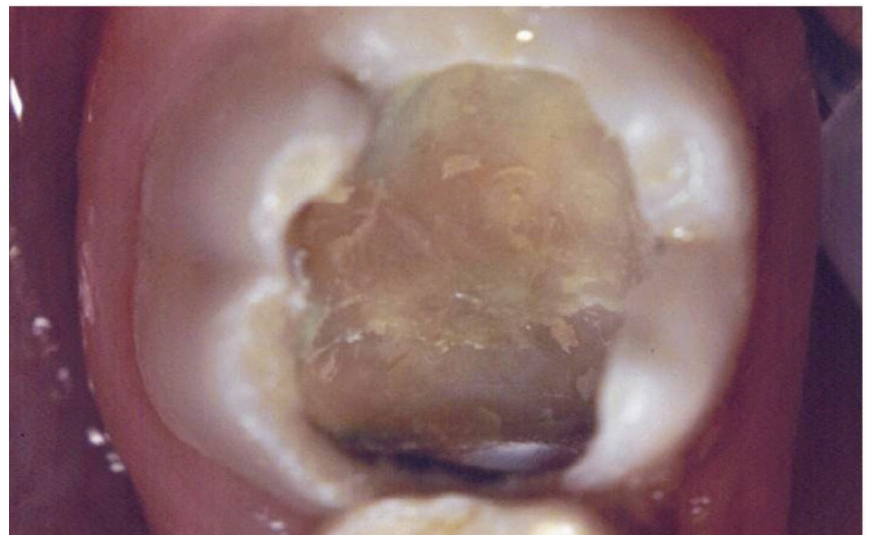

Figure 3. Appearance of dentin of the left mandibular permanent first molar immediately after incomplete removal of carious dentin.

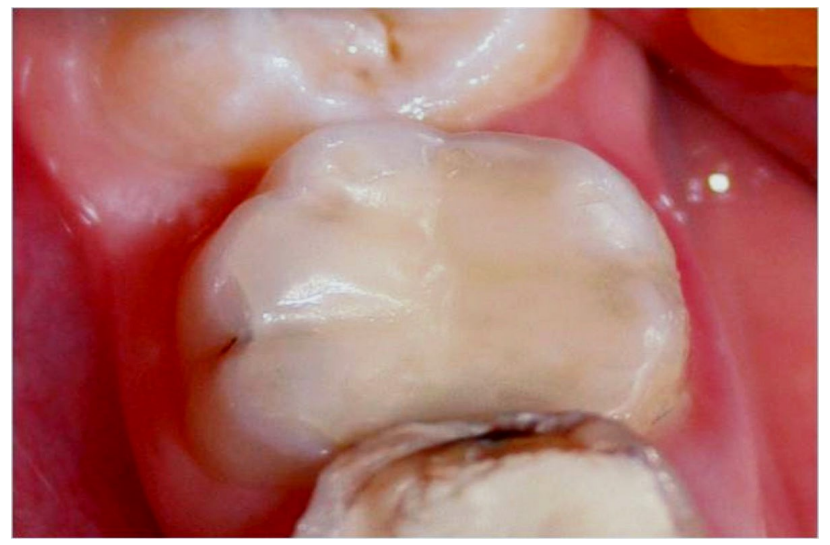

Figure 4. Clinical view of the left mandibular permanent first molar after indirect pulp treatment and restoration with glass-ionomer cement and composite resin
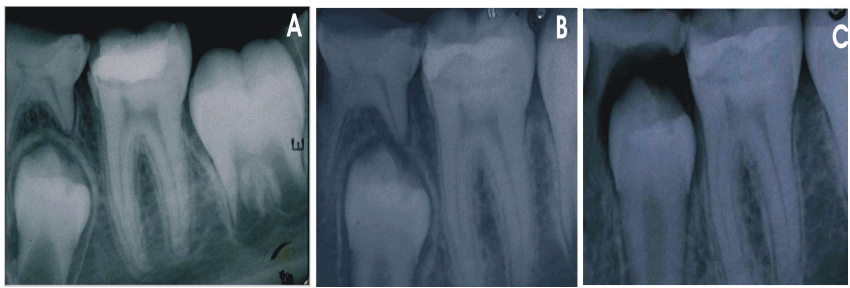

Figure 5. Radiographic evaluation of the left mandibular permanent first molar that received indirect pulp treatment with glass-ionomer cement and composite resin (a) 6 months, (b) one year and (c) 3 years later. Pulp vitality was confirmed and regression of the carious lesion can be observed.

\section{DISCUSSION}

The incomplete removal of carious dentin and the sealing of the cavity with glass-ionomer cement and composite resin without re-entry is a new clinical concept. The treatment of deep caries in only one step can be considered a good alternative to the patient because it can reduce the clinical practice time. This case report was able to show, in a longitudinal follow-up, that indirect pulp treatment in permanent teeth with caries partial removal and cavity sealing without re-entry can be conducted with success, if well indicated.

This kind of treatment has been indicated because it was observed absence of periapical lesion through radiographic examination and lack of spontaneous pain or sensitivity to palpation and percussion. The indirect pulp treatment is usually indicated to reduce an unnecessary risk of pulp exposure leading to a more conservative treatment $t^{3,9-12}$

Studies comparing partial caries removal or stepwise excavation with complete removal of infected tissue from deep carious lesions were discussed in a 2006 Cochrane Review ${ }^{11}$. Stepwise excavation, in deep caries lesions, has been recommended to avoid harm to the pulp tissue. Clinical procedures consist in removing partially the carious dentine and leaving a layer of dentine over the pulp so that it is not mechanically exposed?

After the arrestment of the carious process, it is not advocated that the infected dentine should be removed and a filling be placed ${ }^{5,10,12}$. The mechanism that causes the arrest of deep caries lesions does not seem to differ from that observed in non-cavitated surfaces during tooth eruption ${ }^{13-14}$ or after mechanical removal of biofilm from non-cavitated teeth ${ }^{15}$.

The present study suggests that it is not necessary to reopen the cavity to remove the demineralized dentine as the demineralized dentine, once sealed, can turn from active to inactive and harbors fewer microorganisms. During the reopening of the cavity and removal of remaining decayed dentine, the mechanical procedures may injure the pulp, increasing the risk of pulp exposure and submit the patient to an additional appointment ${ }^{10}$.

Regarding the sealing material, glass-ionomer cement (GIC) has proved to have antimicrobial effects ${ }^{16-18}$. Some in vivo studies have shown less cariogenic plaque adjacent to GIC restorations ${ }^{19}$ and other studies have demonstrated that enamel lesions can be easier remineralized as a result of fluoride release ${ }^{20}$ and consequently diminish the risk for recurrent caries at cavity enamel margins ${ }^{21}$. Kreulen et al..$^{22}$ affirmed that if enamel as well as dentine could benefit from material constituents of glass-ionomer cement, the use of GIC could be a first step towards a new caries therapy. The caries preventive effect of GIC is most likely related to its fluoride release, otherwise it has been shown that an initially high fluoride release decreases after 2-3 months ${ }^{20}$.

The sealing of the cavity after incomplete carious dentine removal produces an increase in radiographic density, indicating mineral gain and apparent arrest of the 
carious process ${ }^{8}$. In this study, this could be observed at the radiographic examination after 6,12 and 36 months. The mineral increase suggests a reaction of the pulp - dentine complex that may be sclerosis, a deposition of tertiary dentine or both. Sclerotic dentine is less permeable than primary dentine ${ }^{23}$ thereby preventing toxic agents from microbial metabolism or materials used for sealing cavities from reaching the pulp. This defense reaction controls inflammation that results from carious process allowing the pulp to repair itself ${ }^{10}$. The ability of the dentine - pulp complex to respond to pulp injuries and materials by hard tissue formation has been recognized ${ }^{24-27}$. Focal deposition of a tertiary dentine matrix is often seen as such responses beneath the site of injury, which have the effect of increasing the distance, and permeability barrier between the injuries and the pulp cells ${ }^{23}$.

In the case of deep caries lesions, odontoblasts under the injury may die, and if suitable conditions prevail within the pulp, reparative dentine matrix can be secreted. Matrix secretion from a new generation of cells implies discontinuity in tubular structure with subsequent reduction in dentine permeability. This permeability of the dentine matrix secreted after injury may be very important in the clinical behavior of the tissues ${ }^{23}$. It has been suggested that for successful outcomes of any operative treatment performed on vital teeth a prime aim should be reduction of dentine permeability as occurs physiologically in dentine in response to injury ${ }^{28}$.

After the secretion of new dentine matrix from the dentine - pulp complex to respond to pulp injuries, the dentine features changes become dominated by a marked dark brownish discoloration in conjunction with a hardening and drying out of the retained dentine ${ }^{29}$. In 1962, Miller and Masster ${ }^{30}$ described similar clinical features to be characteristic of the inactive lesion with dentine involvement. The changes in dentine color and consistency during the treatment appear to be indicative of alternations occurring during caries arrest in dentine ${ }^{6,29}$.

In the present study, it seemed that the carious process was inactivated after incomplete caries removal and sealing of the cavity, evidenced through clinical and radiographic evaluations over a period of 36 months.

\section{CONCLUSION}

On the basis of the results from the present case report, the indirect pulp treatment could be considered a good alternative for the treatment of the deep caries lesions as it reduced the risk of pulp exposure by not reopening the cavity, saved the patient and the dentist clinical time and arrested the lesion progression with radiographic density increase and absence of any pain symptoms after 36 months of follow-up.

\section{Collaborators}

GI SIMONE was responsible for the patient care and help drafting the article; C STEINER-OLIVEIRA took and edited the photographs and wrote the article. MM BRAGA together with the first author, assisted in attendance and reviewed the paper. JCP IMPARATO supervised the research and was responsible for the planning and execution of the treatment plan and writing the article.

\section{REFERENCES}

1. Caufield PW, Li Y, Dasanayake A. Dental caries: an infectious and transmissible disease. Compend Contin Educ Dent. 2005;26(5 Suppl 1):10-6.

2. Kerkhove BC Jr, Herman SC, Klein Al, McDonald RE. A clinical and television densitometric evaluation of the indirect pulp capping technique. J Dent Child. 1967;34(3):192-201.

3. Leksell E, Ridell K, Cvek M, Mejare I. Pulp exposure after stepwise versus direct complete excavation of deep carious lesions in young posterior permanent teeth. Endod Dent Traumatol. 1996;12(4):192-6. doi: 10.1111/j.1600-9657.1996.tb00513.x.

4. Bjorndal L, Kidd EAM. The treatment of deep dentine caries lesions. Dent Update. 2005;32(7):402-13.

5. Maltz M, Oliveira EF, Fontanella V, Carminatti G. Deep caries lesions after incomplete dentine caries removal: 40-month follow-up study. Caries Res. 2007;41(6):493-6. doi:10.1159/000109349.

6. Maltz M, de Oliveira EF, Fontanella V, Bianchi R. A clinical, microbiologic, and radiographic study of deep caries lesions after incomplete caries removal. Quintessence Int. 2002;33(2):151-9.

7. Falster CA, Araujo FB, Straffon LH, Nor JE. Indirect pulp treatment: in vivo outcomes of an adhesive resin system vs calcium hydroxide for protection of the dentin-pulp complex. Pediatr Dent. 2002;24(3):241-8. 
8. Kidd EA. How "clean" must a cavity be before restoration? Caries Res. 2004;38(3):305-13. doi:10.1159/000077770.

9. van Thompson, Craig RG, Curro FA, Green WS, Ship JA. Treatment of deep carious lesions by complete excavation or partial removal: a critical review. J Am Dent Assoc. 2008;139(6):70512. doi: 10.14219/jada.archive.2008.0252.

10. Oliveira EF, Carminatti G, Fontanella V, Maltz M. The monitoring of deep caries lesions after incomplete dentine caries removal: results after 14-18 months. Clin Oral Investig. 2006;10(2):1349.

11. Ricketts DN, Kidd EA, Innes N, Clarkson J. Complete or ultraconservative removal of decayed tissue in unfilled teeth. Cochrane Database Syst Rev. 2006;3:CD003808.

12. Bjørndal L. Indirect pulp therapy and stepwise excavation. J Endod. 2008; 34(7 Suppl):S29-33. doi: 10.1016/j.joen.2008.02.035.

13. Backer DO. Posteruptive changes in dental enamel. J Dent Res 1966;45(3):503-11. doi: 10.1177/00220345660450031101.

14. Carvalho JC, Ekstrand KR, Thylstrup A. Dental plaque and caries on occlusal surfaces of first permanent molars in relation to stage of eruption. J Dent Res. 1989;68(5):773-9. doi: 10.1177/00220345890680050401.

15. Holmen L, Thylstrup A, Artun J. Surface changes during the arrest of active enamel carious lesions in vivo. A scanning electron microscope study. Acta Odontol Scand. 1987;45(6):383-90.

16. Bonecker $\mathrm{M}$, Toi C, Cleaton-Jones P. Mutans streptococci and lactobacilli in carious dentine before and after atraumatic restorative treatment. J Dent. 2003;31(6):423-8. doi: 10.1016/ S0300-5712(03)00065-4.

17. Chin MY, Busscher HJ, Evans R, Noar J, Pratten J. Early biofilm formation and the effects of antimicrobial agents on orthodontic bonding materials in a parallel plate flow chamber. Eur J Orthod. 2006;28(1):1-7. doi: 10.1093/ejo/cji094.

18. Meryon SD, Johnson SG. The modified model cavity method for assessing antibacterial properties of dental restorative materials. J Dent Res. 1989;68(5):835-9. doi: 10.1177/00220345890680051701

19. Hallgren A, Oliveby A, Twetman S. L(+)-lactic acid production in plaque from orthodontic appliances retained with glass-ionomer cement. Br J Orthod. 1994;21(1): 23-6.
20. Forss $H$, Seppa L. Studies on the effect of fluoride released by glass-ionomers in the oral cavity. Adv Dent Res. 1995;9(4):38993. doi: 10.1177/08959374950090040801.

21. Benelli EM, Serra MC, Rodrigues AL Jr, Cury JA. In situ anticariogenic potential of glass-ionomer cement. Caries Res. 1993;27(4):280-4

22. Kreulen CM, de Soet JJ, Weerheijm KL, van Amerongen WE. In vivo cariostatic effect of resin modified glass-ionomer cement and amalgam on dentine. Caries Res. 31(5):384-9.

23. Tziafas $D$, Smith $A J$, Lesot $H$. Designing new treatment strategies in vital pulp therapy. J Dent. 2000;28(2):77-92. doi: 10.1016/ S0300-5712(99)00047-0

24. Harris R, Griffin CJ. The fine structure of the mature odontoblasts and cell rich zone of the human dental pulp. Aust Dent J. 1969;14(3):168-7. doi: 10.1111/j.1834-7819.1969.tb03348.x.

25. Bergenholtz G. Inflammatory response of the dental pulp to bacterial irritation. J Endod. 1981;7(3):100-4. doi: 10.1016/ S0099-2399(81)80122-7

26. Trowbridge $\mathrm{HO}$. Pathogenesis of pulpitis resulting from dental caries. J Endod. 1981;7(2):52-60. doi: 10.1016/S00992399(81)80242-7.

27. Stanley HR. Human pulp response to restorative dental procedures. Grainessville: Storter Printing Company; 1981.

28. Mjor IA. Dentin-predentin complex and its permeability: pathology and treatment overview. J Dent Res. 1985;64(Spec n.):621-7

29. Bjorndal L, Larsen T, Thylstrup A. A clinical and microbiological study of deep carious lesions during stepwise excavation using long treatment intervals. Caries Res. 1997;31(6):411-7.

30. Miller WA, Massler M. Permeability and staining of active and arrested lesions in dentine. Br Dent J. 1962;112:187-7.

Received on: 24/9/2011

Final version resubmitted on: 31/5/2012

Approved on: 17/6/2012 
